\title{
UJI AKTIFITAS TABIR SURYA NANO-TITANIUM OKSIDA UNTUK MENDUKUNG FORMULA KOSMETIK ANTIAGING KHUSUS MENGHAMBAT PENUAAN AKIBAT SINAR MATAHARI
}

\author{
Titik Taufikurohmah ${ }^{\star 1}$, Rusmini ${ }^{1}$, Siti Tjahjani ${ }^{1}$, Gusti Made Sanjaya ${ }^{1}$, Afaf \\ Baktir $^{2}$, and Achmad Syahrani ${ }^{3}$ \\ ${ }^{1}$ Jurusan Kimia, Universitas Negeri Surabaya, Gedung C5, Kampus Ketintang, Jl. Ketintang Surabaya, \\ Surabaya, Indonesia \\ ${ }^{2}$ Departmen Kimia, Universitas Airlangga Surabaya, FST, Kampus C, Jl. Sutorejo Surabaya, Surabaya, \\ Indonesia \\ ${ }^{3}$ Fakultas Farmasi, Universitas Airlangga Surabaya, Gedung Fakultas Farmasi, Kampus B, Jl. Dhamawangsa \\ Dalam, Surabaya, Indonesia
}

*Author utama, email: ttaufikurohmah@yahoo.com; titiktaufikurohmah@unesa.ac.id

Co-author 1, email: rusmini@unesa.ac.id

Co-author 2, email: Siti_tjahjani@unesa.ac.id

Co-author 3, email: igmasanjaya@unesa.ac.id

Co-author 4, email: afafi2003@yahoo.com

Co-author 5, email: asyahrani@ff.airlangga.ac.id

\begin{abstract}
Aging one of problems in social healthy especially in cosmetics community. UV-protection material was important because photo-aging give dominant effect at aging process. The development anti-aging material need exploration sunscreen material too. Utilization of Titanium Oxide in cosmetic formulation have been done. In this research Titanium Oxide was develop to form Nano-Titanium Oxide. It was important to get data that Nano-Titanium Oxide still have sunscreen activity. Spot, wrinkle and decrease of skin moisture were fast condition of aging if face skin get so many sun light especially UV-light with strong energy. In this research used nanomaterial of Titanium Oxide because nanomaterial give so many advantages. The method that used was measure UV absorption this material with UV-visible spectrophotometer instrument. The result of nanomaterial Titanium Oxide that still had sunscreen activity than support anti-aging in cosmetics formulation especially inhibit photo-aging. The impact of this research was the potential using of nanomaterial Titanium Oxide increase as anti-aging material that low level of cost in the future.
\end{abstract}

Keywords: anti-aging, photo-aging, cosmetics, sunscreen, nanomaterial Titanium Oxide.

\section{ABSTRAK}

Pengembangan material antiaging memerlukan ekplorasi, salah satunya melalui pengembangan material tabir surya dalam formula kosmetik. Penuaan adalah salah satu masalah kesehatan masyarakat terutama masyarakat pengguna kosmetik. Material tabir surya sangat penting sebab sinar matahari memberi efek dominan pada proses penuaan. Penggunaan titanium oksida sebagai tabir surya dalam formula kosmetik telah dilakukan. Namun demikian, untuk mendapatkan peningkatan efek tabir surya, pada penelitian ini dikembangkan nano material titanium oksida. Sangat penting untuk mendapatkan data Titanium oksida nano masih memiliki aktivitas tabir surya. Titanium oksida dalam bentuk nanomaterial diuji kemampuan tabir surya dengan menggunakan serapan UV-Vis, diperoleh pergeseran panjang gelombang serapan maksimum $325 \mathrm{~nm}$ menjadi $323 \mathrm{~nm}$ pada hari ke-4 dan diperoleh perhitungan SPF dari nanomaterial $\mathrm{TiO}_{2}$ sebesar $23 \%$, sehingga Titanium oksida dalam bentuk nanomaterial akan meningkat potensinya sebagai antiaging dalam formula kosmetik yang murah di masa mendatang.

Kata Kunci : penuaan, antiaging, formula kosmetik, photoaging, Titanium Oksida. 


\section{PENDAHULUAN}

Penggunaan Titanium oksida pada formula kosmetik sesunggahnya bukan hal yang baru. Titanium oksida dengan bahasa perdagangan pemutih Italy sudah lama dikenal sebagai bahan kosmetik dan juga bahan pemutih beras. Penggunaannya di dalam kosmetik sebagai pemutih yang sifatnya tidak permanen dan hanya pada penggunaan dekoratif saja. Hal ini berarti bahwa efek putih yang ditimbulkan akan hilang bila dibersihkan dari wajah karena itu $\mathrm{TiO}_{2}$ juga sering dijumpai pada bedak tabur karena warnanya yang memang putih. Cara kerja $\mathrm{TiO}_{2}$ sebagai pemutih dalam kosmetik adalah kemampuannya sebagai photo katalis dalam reaksi oksidasi noda yang ada di wajah [1]. Penggunaan $\mathrm{TiO}_{2}$ sebagai katalis dalam reaksi oksidasi reduksi ini termasuk ramah lingkungan dan sedang digalakkan penggunaannya [2].

$\mathrm{TiO}_{2}$ memiliki aktifitas tabir surya yang mampu memantulkan sinar matahari terutama sinar Ultra Violet (UV) yang dengan energi tinggi. Hal ini lebih dikenal dengan istilah physical blocker. Interaksi yang terjadi antara $\mathrm{TiO}_{2}$ dengan material dalam formula kosmetik akan menghasilkan lapisan permukaan atau surface coating [3]. Aktivitas ini menjadikan kulit terlindungi dan tidak menghitam akibat terik matahari. Kulit yang terlindung dari sinar matahari memiliki warna lebih putih karena tidak banyak pigmen melanin yang keluar. Senyawa $\mathrm{TiO}_{2}$ pada akhirnya akan berperan sebagai pemutif melalui mekanisme tersebut. $\mathrm{TiO}_{2}$ tidak bersifat toksik atau membahayakan kesehatan pengguna kosmetik karena telah teruji aman secara pre-klinik pada hewan uji [4].

Pengembangan kosmetik saat ini mengikuti perkembangan teknologi terkini yaitu teknologi nano termasuk pengembangan material sunscreen [5]. Demikian pula dalam pengembangan senyawa tabir surya $\mathrm{TiO}_{2}$ ini juga tidak ketinggalan dengan proses rekayasa material menjadi nano $\mathrm{TiO}_{2}$ [6] . Namun sebelum material nano ini masuk dalam formula kosmetik yang akan dipasarkan maka perlu dilakukan kajian dan penelitian penunjang [7].

Pengembangan kosmetik saat ini telah masuk ke tahapan teknologi nano, termasuk di dalamnya pengembangan material sunscreen [5]. Pengembangan senyawa tabir surya $\mathrm{TiO}_{2}$ telah menjadi bagian dari perkembangan ini, dimana telah marak dilakukan rekayasa nano $\mathrm{TiO}_{2}$ [6]. Material nano memiliki aktivitas lebih tinggi karena pada ukuran ini atom-atom terletak sedemikian rupa sehingga semua atom memiliki jarak ideal untuk beraktivitas dan overlapping antar atom yang minimum pada kondisi ini menginduksi aktivitas maksimal pada seluruh atom.

Untuk memaksimalkan kemanfaatan dan meminimalkan dampak negatif yang mungkin ditimbulkan ketika digunakan dalam kosmetik komersial, penting untuk dilakukan kajian dan penelitian penunjang [7]. Penelitian ini bertujuan untuk mengetahui aktivitas tabir surya nano material $\mathrm{TiO}_{2}$. Aktifitas tabir surya dalam penelitian ini dievaluasi melalui kemampuannya dalam menyerap sinar UV 
yang diukur menggunakan UV-Visible Spektrofotometer.

\section{METODE PENELITIAN}

\section{Alat dan Bahan}

Peralatan gelas digunakan dalam proses sintesis berupa beker glass, pipet tetes, gelas ukur, magnetic sterer, hot-plate, cuvet dan tabung reaksi. Adapun Instrumen yang digunakan adalah Spectrophometer UVVisible Simatzu.

Bahan berupa $\mathrm{TiCl}_{4}$, Natrium sitrat, aquades dan tisu untuk membersihkan peralatan gelas.

\section{Prosedur}

\section{Sintesis Nano $\mathrm{TiO}_{2} 20$ ppm.}

Pada metode sol gel, secara garis besar $\mathrm{TiO}_{2}$ disintesis dari sumber titanium yaitu $\mathrm{TiCl}_{4} 20 \mathrm{ppm}$ yang dipanaskan pada suhu $80^{\circ}$ C. Selanjutnya ditambahkan agen pereduksi Natrium Sitrat dalam ekivalen molaritas. Metode sol gel dapat membuat suatu partikel berukuran nano yang seragam, tidak menggumpal, murni, homogen, dilakukan pada suhu rendah, dan dapat mengontrol distribusi massa. Mensintesis $\mathrm{TiO}_{2}$ nanopartikel dari titanium tetraisopropoksida 20 ppm dengan larutan asam nitrat pada suhu $80^{\circ} \mathrm{C}$. Hasil menunjukan bahwa $\mathrm{TiO}_{2} 20$ ppm nanopartikel yang dihasilkan berbentuk anatase.

\section{Uji Aktivitas tabir surya nano $\mathrm{TiO}_{2} 20 \mathrm{ppm}$}

Koloidal $\mathrm{TiO}_{2}$ yang dihasilkan selanjutnya diukur serapannya pada hari ke2, 3, 4, 5, dan 6 menggunakan instrument UV-Visible. Hal ini dimaksudkan untuk mengetahui karakter serapan UV Visible dari waktu ke waktu. Dikatakan baik apabila serapan UV visible tidak mengalami penurunan dari hari ke hari atau minimal memiliki karakter serapan yang konstan. Bila terjadi penurunan serapan maka sangat tidak menguntungkan sebagai material tabir surya atau sunscreen. Analisis data serapan UV senyawa $\mathrm{TiO}_{2} 20$ ppm dan perhitungan SPF

Analisis data serapan UV dari hasil sintesis nanomaterial $\mathrm{TiO}_{2}$ dilakukan menggunakan grafik atau gambar dengan bantuan fasilitas Exel dari program Microsoft. Perhitungan Sun Protective Factor didapatkan dari rumus berikut:

\section{$\mathrm{SFP}=\mathrm{CF} \times \sum_{290}^{\mathrm{a} 20} E E(\lambda) \times I(\lambda) \times A b s(\lambda)$}

\section{Keterangan:}

SPF/SFP = sun protector Factor (Faktor perlindungan matahari)

$\mathrm{CF}=$ Conversion Factor (Faktor konversi)

$\mathrm{EE}=$ Efectif Eritema (panjang gelombang penyebab eritema/kemerahan kulit)

Adapun harga EE $x$ I untuk rentang panjang gelombang 290-320 nm adalah sebagai berikut:

Tabel 1. Harga EF $\times$ I untuk rentang panjang gelombang 290-320 nm

\begin{tabular}{|l|l|l|}
\hline No & Panjang gelombang & EE X I \\
\hline 1 & $290 \mathrm{~nm}$ & 0.0150 \\
\hline 2 & $295 \mathrm{~nm}$ & 0.0817 \\
\hline 3 & $300 \mathrm{~nm}$ & 0.02874 \\
\hline 4 & $305 \mathrm{~nm}$ & 0.03278 \\
\hline 5 & $310 \mathrm{~nm}$ & 0.1864 \\
\hline 6 & $315 \mathrm{~nm}$ & 0.0839 \\
\hline 7 & $320 \mathrm{~nm}$ & 0.0180 \\
\hline Total & & 1 \\
\hline
\end{tabular}


Selanjutnya SPF dihitung dari total perkalian EE $x$ I dengan serapan pada tiap panjang gelombang [8].

\section{HASIL DAN PEMBAHASAN}

Hasil serapan UV-Visible hasil sintesis $\mathrm{TiO}_{2}$

Pengukuran serapa UV Visible dari senyawa nano $\mathrm{TiO}_{2}$ dilakukan pada hari ke-2, $3,4,5$ dan 6 untuk mengetahui $\lambda$ maksimum serapan. Hal ini berhubungan dengan kestabilan koloidal yang dihasilkan. Selanjutnya pengukuran serapan UV juga dilakukan pada rentang panjang gelombang 290-320 nm untuk menghitung SPF dari nanomaterial $\mathrm{TiO}_{2}$.

Hasil serapan UV-visible Nanomaterial berada pada rentang panjang gelombang 285 $\mathrm{nm}$ sampai dengan $400 \mathrm{~nm}$ yang merupakan wilayah UV-B, dengan demikian $\mathrm{TiO}_{2}$ dikategorikan sebagai senyawa tabir surya atau anti UV-B dalam formula kosmetik. Adapun besarnya serapan atau Absorbansi dari senyawa ini sebagaimana terlihat pada Tabel 1. Serapan UV $\mathrm{TiO}_{2}$ tergolong baik karena selama pengukuran tidak mengalami penurunan bahkan mengalami kenaikan serapan.

\section{Analisis Serapan UV}

Analisis serapan UV dari hasil sintesis Nano $\mathrm{TiO}_{2}$ dilakukan secara deskriptif menggunakan gambar atau grafik dari Program EXEL sebagaimana dapat dilihat pada Gambar 2. Grafik memiliki karakter yang meningkat atau dengan gradient positif yang artinya terjadi peningkatan serapan dari waktu ke waktu selama pengukuran. Hal ini memberikan petunjuk bahwa formulasi dapat dilakukan setelah beberapa hari dari proses sintesis.

\section{Analisis Pergeseran Serapan UV}

Dari data pada Tabel 1. Terlihat bahwa terjadi pergeseran serapan dari hari ke-4 pengukuran dari harga panjang gelombang serapan maksimum $325 \mathrm{~nm}$ menjadi $323 \mathrm{~nm}$. Hal ini menunjukkan bahwa partikel nano yang dihasilkan mengalami agregasi pada hari ke-4 setelah sintesis. Dengan demikian untuk lebih amannya maka formulasi dilakukan setelah hari ke-4 ini.

Tabel 2. Data Serapan UV maksimum Nano $\mathrm{TiO}_{2}$

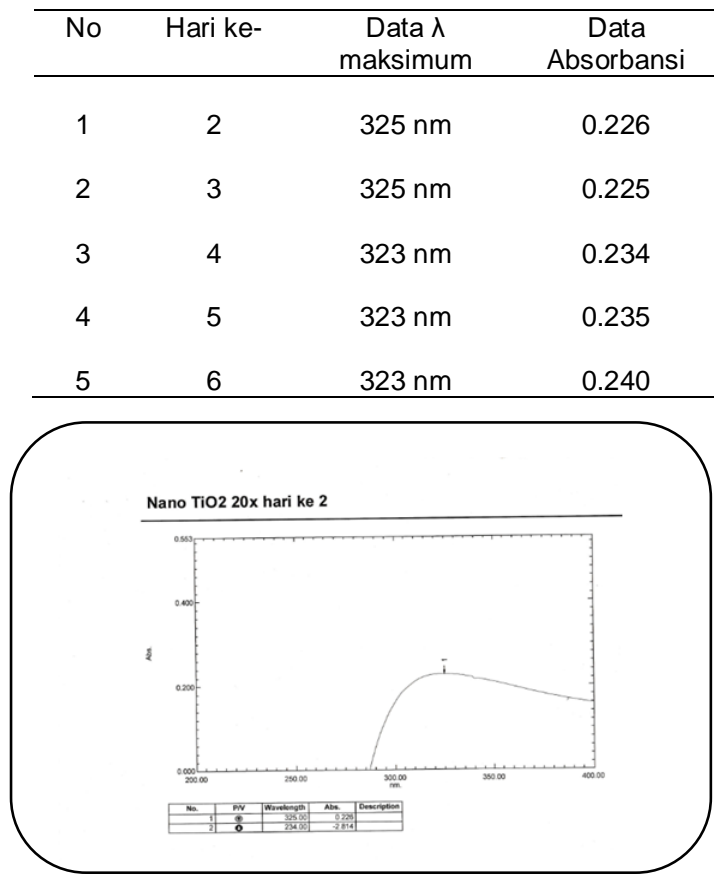

Gambar 1. Serapan UV Nano- $\mathrm{TiO}_{2}$ hari ke-2

Karakterisasi terhadap material Nano $\mathrm{TiO}_{2}$ ternyata sangat sesuai dengan yang diharapkan sebagai material tabir surya masa depan yang harganya terjangkau dengan keunggulan yang dapat dibanggakan dimana selain memiliki serapan UV yang meningkat dari hari-ke hari, juga dalam konsentrasi yang 


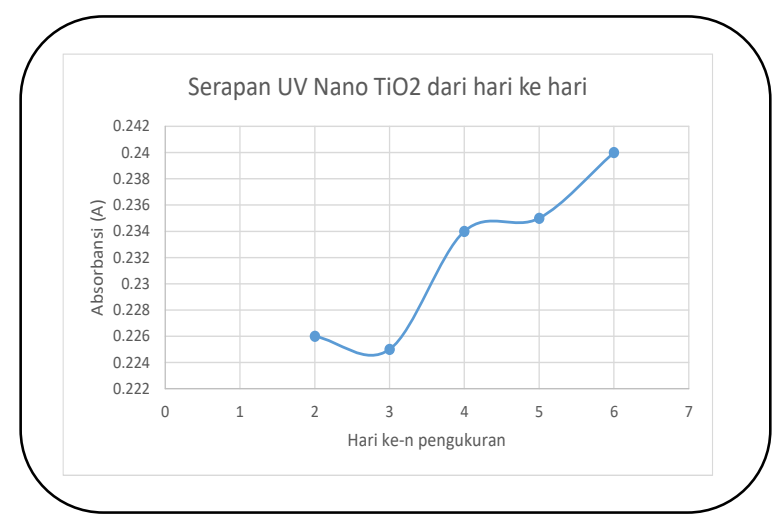

Gambar 2. Peningkatan serapan Nano TiO2 hari $2-6$

\section{Perhitungan SPF}

Tabel 3. Data serapan UV pada $\wedge 290-320 \mathrm{~nm}$

\begin{tabular}{|l|l|l|}
\hline No & $\begin{array}{l}\text { Panjang gelombang } \\
(\lambda)\end{array}$ & $\begin{array}{l}\text { Absorbansi } \\
(\mathrm{A})\end{array}$ \\
\hline 1 & $290 \mathrm{~nm}$ & 0.245 \\
\hline 2 & $295 \mathrm{~nm}$ & 0.241 \\
\hline 3 & $300 \mathrm{~nm}$ & 0.237 \\
\hline 4 & $305 \mathrm{~nm}$ & 0.232 \\
\hline 5 & $310 \mathrm{~nm}$ & 0.227 \\
\hline 6 & $315 \mathrm{~nm}$ & 0.224 \\
\hline 7 & $320 \mathrm{~nm}$ & 0.218 \\
\hline
\end{tabular}

Tabel 4. SPF Nanomaterial $\mathrm{TiO}_{2}$

\begin{tabular}{|l|l|l|l|}
\hline$\lambda(\mathrm{nm})$ & Absorbansi & EE $x$ I & SPF \\
\hline $290 \mathrm{~nm}$ & 0.245 & 0.0150 & 0.003675 \\
\hline $295 \mathrm{~nm}$ & 0.241 & 0.0817 & 0.0196897 \\
\hline $300 \mathrm{~nm}$ & 0.237 & 0.02874 & 0.0681138 \\
\hline $305 \mathrm{~nm}$ & 0.232 & 0.03278 & 0.0760496 \\
\hline $310 \mathrm{~nm}$ & 0.227 & 0.1864 & 0.0423128 \\
\hline $315 \mathrm{~nm}$ & 0.224 & 0.0839 & 0.0187936 \\
\hline $320 \mathrm{~nm}$ & 0.218 & 0.0180 & 0.003924 \\
\hline SPF Total $=$ & & 0.2325585 \\
\hline
\end{tabular}

rendah 20 ppm sudah cukup. Dengan demikian formula kosmetik dapat menggunakan senyawa ini dalam konsentrasi rendah. Selama ini $\mathrm{TiO}_{2}$ yang digunakan dalam formula adalah $10 \mathrm{~g}$ tiap $\mathrm{kg} \mathrm{Krim}$, hal ini berarti $0,1 \%$ sama dengan $1000 p p m . \mathrm{TiO}_{2}$ dalam bentuk nanopartikel juga telah diuji penggunaannya sebagai senyawa tabir surya pada masyarakat sehingga aspek pemasaran juga telah siap untuk komersialisasi yang lebih luas [9].

Ternyata $\mathrm{TiO}_{2}$ Nanopartikel juga telah digunakan dalam produk pangan dan telah dikaji dalam penelitian pendukung untuk memastikan keamanan dan interaksi dengan system metabolism tubuh [10]. Namun demikian uji toksisitas terhadap sel saraf dan Otak perlu dilakukan lebih mendalam [11]. Pemanfaatan nanomaterial $\mathrm{TiO}_{2}$ dalam produk makanan dan produk perawatan tubuh telah dilakukan karena tergolong material yang ramah lingkungan dan tidak membahayakan [12]. Peran $\mathrm{TiO}_{2}$ dalam proses deferensiasi sel juga telah menjadi perhatian para peneliti untuk memastikan keamanan tingkat sel karena bagaimanapun material nano mampu terpenetrasi dalam organela di dalam sel biologis [13]. Penggunaan $\mathrm{TiO}_{2}$ dalam formula kosmetik tidak perlu diragukan karena juga memiliki kemampuan sebagai antibakteri yang juga telah dilaporkan dalam hasil penelitian [14]. Titanium dioksida juga telah diaplikasikan sebagai material biomedis dimana digabung dalam bentuk hibrida atau gabungan dengan material yang lain dan memberikan keamanan yang cukup baik [15]. Titan dioksida juga telah digunakan dalam industri tekstil dengan aspek masa depan yang sangat menjanjikan selain sebagai pemutih juga penghilang noda secara otomatis karena bersifat fotokatalitik oksidasi warna/noda [16].

Dari data pada Tabel 3 diperoleh informasi perhitungan SPF dari nanomaterial $\mathrm{TiO}_{2}$ sebesar 0,23 atau 23 persen atau lebih dikenal dengan istilah umum SPF sama 
dengan 23. Perlu diketahui bahwa konsentrasi $\mathrm{TiO}_{2}$ hanya 20 ppm sudah memberikan perlindungan terhadap sinar matahari atau sinar UV sebesar $23 \%$. Bila konsentrasi naik makan SPF material juga naik.

\section{KESIMPULAN}

Hasil sintesis yang berupa nanomaterial $\mathrm{TiO}_{2}$ masih memiliki aktivitas tabir surya yang stabil bahkan meningkat serapan UV nya dari waktu ke waktu. Dengan demikian $\mathrm{Nano} \mathrm{TiO}_{2}$ dapat digunakan sebagai senyawa tabir surya yang mendukung kosmetik antiaging dengan menghambat photoaging.

\section{UCAPAN TERIMAKASIH}

Terimakasih diucapkan pada pemerintah Republik Indonesia melalui Kemenristek-Dikti dan LPPM Universitas Negeri Surabaya yang telah mendanai dan menyalurkan dana pada peneliti. Penelitian ini merupakan bagian tak terpisahkan dari pengembangan material kosmetik yang mendukung kegiatan PUSN 2017 yang berjudul Pabrikasi Kosmetik Nanogold untuk Mendukung Industri Kosmetik Dalam Negeri.

\section{DAFTAR PUSTAKA}

[1] Anpo, M. (2004). Preparation, characterization, and reactivities of highly functional titanium oxide-based photocatalysts able to operate under UV-visible light irradiation: Approaches in realizing high efficiency in the use of fisible light. Bull Chem Soc Jpn:77, 1427-1442.doi:10.1246/bcsj.77.1427.

[2] Arnall, A. (2003). Future technologies, today's chices. London: Greenpeace Enviromental Trust.

[3] Barker, P., \& Branch, A. (2008). The interaction of modern sunscreen formulations with surface coatings. Prog Org Coat (62), 313320.doi:10.1016/j.porgcoat.2008.01.008.

[4] Bermudez, E., Mangun, J., Wong, B., Asgharian, B., Hext, P., Warheit, D., \& Everitt, J. (2004). Pulmonary responses of mice, rats, and hamsters to subchronic inhalation of ultrafine titanium dioxide particles. Toxicol Sci:77, 357.doi:10.1093/toxsci/kfh019[pubmed]

[5] Berube, D. (2008). Rhetorical gamesmanship in the nano debates over sunscreen and nanoparticles. Journal Nanopart Res: 10, 23-37. doi: 10.1007/s11051-008-9362-7.

[6] Chen, X., \& Mao, S. (2007). Titanium Dioxide Nanomaterials: Synthesis, properties, modifications, and applications. Chem Rev:107, 2891-2959. doi: 10.1021/cr0500535[pubmed].

[7] Breggin, L., Falkner, R., Jarpers, N., Pendergrass, J., \& Porter, R. (2009). Securing the promise of nanotechnologies. London: Chatham House(the Royal Institute of International Affairs).

[8] Haddad, Nick M., Bowne, David R., Cunningham, Alan., Danielson, Brent J., Levey, Douglas J., Sargent, Sarah., Spira,Tim. (2003). Corridor Use by Diverse Taxa. Ecology, 84(3),609-615.

[9] Johannes F, J., lbo, V. d., \& Patricia, O. (2010). Sunscreen with Titanium Dioxide (TiO2) NanoParticles: A Societal Experiment. Nanoethics, 4 (2) Springer , 103-113: doi: 10.1007/s11569-010-0090y.

[10] Pedro, A. R., Belen, M., Hele, M. B., Silvia, L., Kristin, A., Marianne, R. S., . . Gerhard, R. (2017). Titanium dioxide nanoparticles exacerbate DSSinduced colitis: role of the NLRP3 inflammasome. GUT 66(7), 12-16 doi: 10.1136/gutjnl-2015-310297.

[11] Bin, S., Jia, L., Xiaoli, F., Limin, W., \& Longguan, S. (2015). A review on potential neurotoxicity of Titanium Dioxide Nanoparticles. Nanoscale Res Left Volume 10, 342 doi: 10.1186/s11671-0151042-9.

[12] Weir, A., Westerhoff, P., Fabricius, L., Hristovski, K., \& Von, G. N. (2012). Titanium Dioxide Nanoparticles in food and personal care products. Environ Sci Technol Vol 46(4), 2242-2250 doi: 10.1021/es204168d. [PubMed].

[13] Logan, N., Sherif, A., Cross, A., Collins, S., Trynor, A., \& Bozec, L. (2015). TiO2-coated CoCrMo improving the osteogenic differentiation and adhesion of mesenchymal stem cells in vitro. $J$ Biomed Mater Res Part A 103(3), 1208-1217 doi: 10.1002/jbmr35264.

[14] Wu, Q., Li, J., Zhang, W., Qian, H., She, W., \& Pan, $H$. (2014). Antibacterial property, angiogenic and osteogenic activity of $\mathrm{Cu}$-incorporated $\mathrm{TiO} 2$ coating. J Mat Chem B 2(39), 6738-6748 doi: 10.1039/C4TB00923A

[15] Catauro, M., Bollino, F., Papale, F., Marciano, S., \& Pacifico, S. (2014). TiO2/PCL hybrid materials synthesized via sol-gel technique for biomedical applications. Mater Sci Eng C 47, 135-141 doi: 10.1016/j.msec.2014.11.040[PubMed].

[16] Montazer, M., \& Pakdel, E. (2011). Functionality of Nano Titanium dioxide on textiles with future aspects: Focus on wool. J Photochem Photobiol CPhotochem Rev. 12(4), 293-303: doi: 10.1016/jjphotochemrev.2011.08.005 